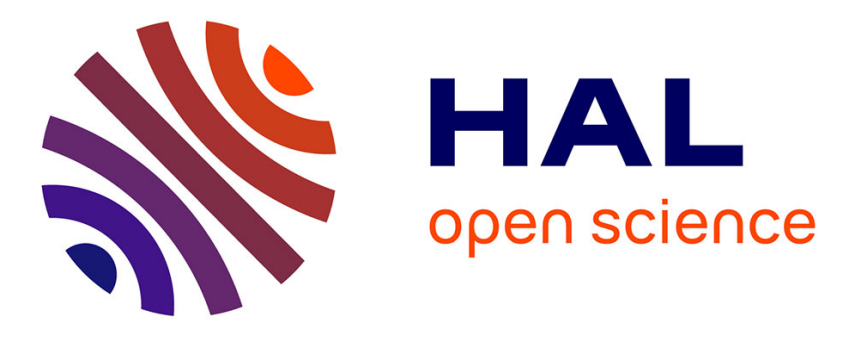

\title{
The first Palaeodictyoptera (Insecta) from the Carboniferous-Permian basin of Graissessac (France)
}

Antoine Logghe, Romain Garrouste, Jean-Sebastien Steyer, Jean-Marc Pouillon, André Nel

\section{To cite this version:}

Antoine Logghe, Romain Garrouste, Jean-Sebastien Steyer, Jean-Marc Pouillon, André Nel. The first Palaeodictyoptera (Insecta) from the Carboniferous-Permian basin of Graissessac (France). Historical Biology, 2021, 34 (3), pp.486-492. 10.1080/08912963.2021.1929953 . hal-03257982

\section{HAL Id: hal-03257982 https://hal.sorbonne-universite.fr/hal-03257982}

Submitted on 11 Jun 2021

HAL is a multi-disciplinary open access archive for the deposit and dissemination of scientific research documents, whether they are published or not. The documents may come from teaching and research institutions in France or abroad, or from public or private research centers.
L'archive ouverte pluridisciplinaire HAL, est destinée au dépôt et à la diffusion de documents scientifiques de niveau recherche, publiés ou non, émanant des établissements d'enseignement et de recherche français ou étrangers, des laboratoires publics ou privés. 
3 The first Palaeodictyoptera (Insecta) from the Carboniferous-Permian basin

\section{of Graissessac (France)}

5

Antoine Logghe ${ }^{\mathrm{a}}$, Romain Garrouste ${ }^{\mathrm{b}}$, Jean-Sebastien Steyer ${ }^{\mathrm{a}}$, Jean-Marc Pouillon ${ }^{\mathrm{c}}$ and Andre $\mathrm{Nel}^{\mathrm{b}, *}$

Running head

Palaeodictyopteran insect from Graissessac

${ }^{a}$ Centre de Recherches en Paléontologie de Paris, UMR 7202 - CNRS, MNHN, SU, EPHE, Muséum National d'Histoire Naturelle, 8 rue Buffon, CP38, F-75005 Paris, France. E-mails: antoine.logghe@,orange.fr, jean-sebastien.steyer@mnhn.fr

bInstitut de Systématique, Evolution, Biodiversité (ISYEB), Muséum national d'Histoire naturelle, CNRS, Sorbonne Université, EPHE, Université des Antilles, CP 50, 57 rue Cuvier, F-75005 Paris, France. E-mails: garroust@mnhn.fr, anel@mnhn.fr ${ }^{\mathrm{c}} 179$ Rue des Plattières, 38300, Nivolas Vermelle, France. E-mail: jmpdb@wanadoo.fr

Antoine Logghe: https://orcid.org/0000-0002-2854-77

Jean-Sébastien Steyer: https://orcid.org/0000-0003-1835-7852

Romain Garrouste: https://orcid.org/0000-0002-0880-5781

Jean-Marc Pouillon: https://orcid.org/0000-0001-6016-4734

André Nel: https://orcid.org/0000-0002-4241-7651 
* Corresponding author

\section{ABSTRACT}

A new dictyoneurid insect, Dictyoneura goujonorum n. sp. from the Latest Ghzelian - Asselian basin of Graissessac (Hérault, France) is described in details. It is represented by a wellpreserved specimen with wings of 32-35 mm long and 13-14 mm wide and other peculiar diagnostic characters such a MP with four branches and a CuP with three branches. As all the other Dictyoneura species are known from the Namurian and/or the Wesphalian, Dictyoneura goujonorum n. sp. is the youngest representative of the genus. It is also the first record of the order Palaeodictyoptera from the Graissessac basin. The Carboniferous-Permian palaeodictyopterans are well-known to have lived in rather humid swamp forests. The global warming and drying of the climate during the Permian and/or the rise of potential predators may be responsible of their extinction.

\section{KEYWORDS}

Insecta; Palaeoptera; Carboniferous-Permian; Capitanian extinction; climatic changes; France.

\section{Introduction}

The Palaeodictyoptera are major herbivorous sucking insects known from the Late Carboniferous to the Early Permian. They were well-diversified, with at least known 50 genera in about 16 families (see Fossilworks database at http://fossilworks.org). However the palaeodictyopteran species are generally represented by very few specimens in comparison to other clades such as the Dictyoptera or the Archaeorthoptera (A.N. pers. obs.). Thus, any new fossil of these strange six-winged insects is welcome to improve our knowledge on their diversity and temporal range. Palaeodictyoptera are known of the swamp forests of the Late 
Carboniferous, with a maximum of diversity in the well-known outcrop of Commentry (northern part of the French Massif Central) (Kukalová 1969a-b, 1970). They are generally associated with the warm and humid evergreen coal forests, together with some of their emblematic predators, the giant odonatopterans Meganeuridae called griffenflies. Some Palaeodictyoptera are also very large insects (e.g. Homoioptera gigantea Agnus, 1902 with a wing span of ca. $40 \mathrm{~cm}$ ), but most of them were relatively small, with wing span ca. $10 \mathrm{~cm}$.

The Latest Carboniferous - Earliest Permian Graissessac basin (Hérault, France) is a quite favorable area to find fossils of plants. Numerous geological researches, mainly linked to the exploitation of the coal, have been undertaken since the $19^{\text {th }}$ century. The collect of fossil animals is decreasing since these last decades with the closure of these coal mines. The insect record is especially scarce. Thanks to the efforts of Mr and Mrs Goujon Claude and Monique, more fossils have been found recently. Here we describe in details the first Palaeodictyoptera from the Graissessac basin. It is also the first fossil insect properly described for this outcrop. It is compared with all the other dictyoneurid genera. This new finding addresses our knowledge on the Carboniferous-Permian fauna of Graissessac. It is also the latest occurrence of this genus and therefore contribute to document the putative extinction of the clade before the Middle Permian.

\section{Material and methods}

The type specimen was collected in 2019 by Goujon and Monique Claude, in the dump issued of the open coal mine named 'Carrière de Layrac' (North East of the town of Graissessac). The Graissessac basin is situated in the southern part of the Massif Central, France. Its general orientation is west to east, forming a long synclinal of $30 \mathrm{~km}$ long and $2.5 \mathrm{~km}$ wide (Fig. 1) (Martín-Closas and Galtier 2005: fig. 1). Becq-Giraudon (1973) considered this basin as a channel of sedimentation flow and plant debris-flow alimenting a larger Carboniferous basin 
located under the Permian sediments of Lodève. Seven to eight coal layers have been identified, one of them being up to six meters thick on average. They are interbedded between layers of sandstone and shale. The recent sedimentological study of these rocks allows to recognize a great diversity of depositional environments: torrential alluvial cones, fluvial environments of variable energy, flood plains and swamps in an intra-mountain sedimentary basin (Saint Martin 1993; Rilliart 2013). These environments may have developed in a relatively low basin region framed by very high mountains (Becq-Giraudon and Van den Driessche 1993), forming possibly what we called here a "lost valley". Indeed sedimentological data (exhaust craters, solifluxion flows, ice crystal ghosts) suggest the presence of periglacial phenomena and a rather cool paleoclimate for the Graissessac area (Becq-Giraudon and Van Den Driessche 1994; BecqGiraudon et al. 1996).

Concerning the age of the Graissessac basin, Bruguier et al. (2003) estimated it around $295.5 \pm 5.1 \mathrm{Ma}$, that-is-to-say Asselian (earliest Permian) based on zircon geochronology. However its plant assemblage suggests a late Gzhelian (latest Carboniferous) age (Poschmann et al. 2016). This Graissessac flora includes about 70 taxa of lycopsids, sphenopsids, pteridosperms, and prephanerograms (Grand'Eury 1877; Becq-Giraudon 1973; Doubinger, 1983 Poschmann et al. 2016): these taxa are relatively well-known in the CarboniferousPermian rocks of the other Massif Central and European basins (e.g. Doubinger et al. 1995). The presence of very large trunks of Sigillaria and Calamites suggests an environment of flood plains and swamps, also supported by Martín-Closas and Galtier (2005).

The animal fossil record is reduced. Mostly invertebrate have been recovered: Mollusca: Carbonicola sp. (Becq-Giraudon 1973); Arthropoda: xiphosuran Euproops mariae (Crônier and Courville, 2005), Chelicerata Aenigmatarbus rasteli Poschmann et al., 2016 and Scorpiones Eoscorpius sp., Compsoscorpius sp. (Poschmann et al. 2016); Insecta: Paoliida Blattinopsis sp., a wing of a Polyneoptera 'Prothortoptera' (Becq-Giraudon 1972) and the endophytic 
oviposition of an insect, possibly an Odonatoptera (Béthoux et al. 2004); Vertebrata: 'fishes' have been mentioned but not described (Bergeron 1889; Louis 1954) and a branchiosaurid recently excavated is currently under description by us. Trace fossils have also been found in the Graissessac basin with the presence of trackways of the millipede-like Arthropleura sp. (Moreau et al. 2019). Compared with the faunas of the other Massif Central basins, this fauna is reduced in specimen number but well-diversified, with representatives of several major groups of organisms. This suggests that the biota of the Graissessac "lost valley" already presents complex trophic chains.

The photographs were taken using Nikon D800 camera with $60 \mathrm{~mm}$ 2,8 Micro Nikkor lens in the 3D Lab (ISYEB, MNHN), and the reconstruction of the venation was done under a binocular microscope Nikon SMZ 1500, with a camera lucida.

We follow the wing venation terminology of Kukalová-Peck (1991).

Institutional abbreviations.-MHNE, Muséum d'Histoire Naturelle et d'Ethnologie of Colmar, France.

Other abbreviations.- $\mathrm{A}$ anal veins; $\mathrm{C}$ costal vein; $\mathrm{CuA}$ cubitus anterior; $\mathrm{CuP}$ cubitus posterior; MA median anterior; MP median posterior; RA radius anterior; RP radius posterior; $\mathrm{ScP}$ subcostal posterior.

Nomenclatural acts.-This published work and the nomenclatural acts it contains, have been registered in urn:lsid:zoobank.org:pub:9220BD12-40CC-4181-8F90-798E433CDE55

\section{Systematic palaeontology}

Order: Palaeodictyoptera Goldenberg, 1877

Superfamily: Dictyoneuroidea Handlirsch, 1906a

Family: Dictyoneuridae Handlirsch, 1906a 
127

128

129

130

131

132

133

134

135

136

137

138

139

140

141

142

143

144

145

148

149

150

146 Type locality

147 Quarry of Layrac, Graissessac, Hérault, France (GPS coordinates available to qualified

Type species

Dictyoneura libelluloides Goldenberg, 1854 (Westphalian D, Saar basin, Germany)

Other species

Dictyoneura kemperi Brauckmann and Koch, 1983 (Namurian, Hagen-Vorhalle, Germany), Dictyoneura nigra Kliver, 1883 (Westphalian C, Saar basin), and Dictyoneura goujonorum n. sp.

Dictyoneura goujonorum n. sp.

(Figure 2)

urn:1sid:zoobank.org:act:53F972EE-42A0-4F24-8A86-17D2A9073275

Etymology

Named after Goujon Claude and Monique who found the type specimen.

\section{Type material}

MHNE.2021.3.1 (imprint and counter-imprint of a fore- and a hind wing in life position with fragments of abdomen and thorax), stored at the Muséum d'Histoire Naturelle et d'Ethnologie of Colmar, France. researchers). 
Diagnosis

154

155

156

157

158

159

Wings ca. 32.0-35.0 mm long, and 13.0-14.0 mm wide; ScP elongate; RP not pectinate; MA simple; MP with four branches; CuA simple; $\mathrm{CuP}$ with three branches; bases of $\mathrm{CuA}$, MA and RP approximate.

\section{Description}

Wings without trace of coloration; forewing ca. $35.0 \mathrm{~mm}$ long, $13.0 \mathrm{~mm}$ wide; anterior margin not curved basally; costal area $1.0 \mathrm{~mm}$ wide; $\mathrm{ScP}$ at least $29.0 \mathrm{~mm}$ long, terminating on $\mathrm{C}$ well beyond midwing; RA simple; base of RP $11.0 \mathrm{~mm}$ from wing base; RP not pectinate, with two main branches, anterior one forked and posterior one with two-three branches; MA unbranched, weakly curved basally, separated from MP slightly basal to base of RP, $1.0 \mathrm{~mm}$ apart; MP with two main branches, each of them being forked again; $\mathrm{CuA}$ unbranched, weakly curved basally, separated from CuP slightly basal to base of MA, $2.0 \mathrm{~mm}$ apart; CuP with two-three branches; anal area $4.0 \mathrm{~mm}$ wide, anal veins poorly preserved; archaedictyon present but poorly visible. Hind wing ca. $32.0 \mathrm{~mm}$ long, $14.0 \mathrm{~mm}$ wide; triangular-shaped and with a broader anal area than in forewing; costal area as broad as that of forewing, $1.0 \mathrm{~mm}$ wide; venation identical to that of forewing; cubito-anal area broader than that of forewing, $6.0 \mathrm{~mm}$ wide.

\section{Discussion}

This fossil belongs to the Palaeodictyoptera rather than to the other orders of the Palaeodictyopterida because of the dense venation, with numerous branches of main veins, and the simple pattern of branching of RP and MA (Carpenter 1992). Riek (1976) proposed a key to palaeodictyopteran superfamilies, after which Dictyoneura goujonorum n. sp. would fall in 
the Dictyoneuroidea, because of the following characters: CuA and MA simple; ScP separated from R; Archaedictyon present. But after Riek (1976), the representatives of this superfamily would also have MP simple or three-branched, which is not the case for the type genus Dictyoneura and Dictyoneura goujonorum n. sp.

The current classification of the Palaeodictyoptera is not satisfactory. Sinitshenkova (2002: fig. 138) first proposed a phylogenetic hypothesis, but the absence of real outgroup(s) to basically polarize the character states, and the basal-most dichotomy established on the character ['wings wide basally' vs. 'wing base narrow'], with the two states supposedly supporting the two branches, while one should be plesiomorphic, prevent a total confidence to these results. Sroka et al (2015: fig. 11) proposed another hypothesis, better supported by true outgroups and computer treatment of the data, in which the order Palaeodictyoptera falls as a grade, sister group of the (Megasecoptera + (Permothemistidae + Diaphanopterodea)).

A comparison of this fossil to all the currently accepted families (as listed in the fossilworks database http://fossilworks.org) is necessary:

- the 'anterior margin of the wing not curved basally' excludes the Lithomanteidae Handlirsch, 1906;

- $\quad$ the posteriorly curved branches of M and Cu exclude the Megaptilidae Handlirsch 1906; - the less elongated wings, with only three branches of MP instead of six, and the shorter abal area differs from Archaemegaptilus kiefferi Meunier, 1908 (Kukalová 1969: fig. 46) and exclude the Archaemegaptilidae Handlirsch, 1919;

- the 'RP and MA not coalescent nor strongly approximate' excludes the Eugereonidae Handlirsch, 1906a;

- the elongate ScP excludes the Calvertiellidae Martynov, 1931 and the Stobbsiidae Handlirsch, 1908 (Laurentiaux and Laurentiaux-Vieira, 1951: fig. 5);

- the 'branched MP' excludes the the Tchirkovaeidae Sinitshenkova, 1979; 
- the 'CuA simple' excludes the Homoiopteridae Handlirsch, 1906a, Spilapteridae Handlirsch, 1906a, Fouqueidae Handlirsch, 1906a, Elmoboriidae Carpenter, 1976;

- the 'MA simple' excludes the Homothetidae Scudder, 1885 based on a poorly known fossil; more branches of RP and MP and a forked CuA (Handlirsch 1906b). The Synarmogidae 
Affinities with the Breyeriidae Handlirsch, 1906a are more complicate to exclude. They generally have long crossveins between the main veins and their branches (viz. in Breyeria de Borre, 1875, Jugobreyeria Brauckmann et al., 1985, Hasala Brauckmann, 1995, Megaptiloides Handlirsch, 1906, and Vermooija Prokop et al., 2018), not present in Dictyoneura goujonorum n. sp. Thus this character would be sufficient to exclude affinities of Dictyoneura goujonorum n. sp. with the Breyeriidae. But in Aviobreyeria Prokop et al., 2013, these crossveins are mainly present in the distal half of the wing while there is an archedictyon in basal part of wing. The Breyeriidae can have a short ScP, ending at the level of first branch of anterior branch of RP (in Breyeria, Jugobreyeria) or an elongate one (in Hasala, Aviobreyeria, Megaptiloides, and

Dictyoneura goujonorum n. sp. has all the diagnostic characters of the Dictyoneuridae (as proposed by Carpenter 1992: 28). They share the absence of well-defined crossveins all $\mathrm{CuP}$ not simple, main veins posteriorly curved, ScP elongate, no trace of crossveins in costal area.

Dictyoneura, with the three species Dictyoneura libelluloides, Dictyoneura kemperi, and Dictyoneura nigra. Waterlot (1934) included the two species Dictyoneura rugosa Handlirsch, 1906a and Dictyoneura sinuosa Kliver, 1883 in this genus. Lastly Dictyoneura higginsii 
genus. Dictyoneura sinuosa probably does not belong to this genus because its base of $\mathrm{CuA}$ and of RP are well basal to that of MA (Waterlot 1934: pl. 17, fig. 1). Also, Dictyoneura rugosa (based on a fragment of mid part of wing) probably does not belong to this genus because the base of $\mathrm{CuA}$ is well basal to that of MA (Waterlot 1934: text-fig. 43). Dictyoneura kemperi has five branches of MP, unlike four in the other species and Dictyoneura goujonorum sp. nov. But the value of this character remains uncertain because of the lack of information on the variations in the number of branches of the main veins in these insects. Dictyoneura kemperi has forewings ca. $43 \mathrm{~mm}$ long, $16 \mathrm{~mm}$ wide, and the hind wings ca. $39 \mathrm{~mm}$ long and $16 \mathrm{~mm}$ wide. Dictyoneura libelluloides has wings more than $55 \mathrm{~mm}$ long and $22 \mathrm{~mm}$ wide, after Waterlot (1934: 141), and/or wings more than $57 \mathrm{~mm}$ long and $22 \mathrm{~mm}$ wide, after Guthörl (1934: 52). Dictyoneura nigra has wings more than $44 \mathrm{~mm}$ long and $18 \mathrm{~mm}$ wide after Waterlot (1934: 142), and/or more than $35 \mathrm{~mm}$ long and $18 \mathrm{~mm}$ wide, after Guthörl (1934: 53). Dictyoneura goujonorum n. sp. is clearly a smaller insect with forewing ca. $35 \mathrm{~mm}$ long, $13 \mathrm{~mm}$ wide, and hind wing ca. 32 mm long, $14 \mathrm{~mm}$ wide.

\section{Conclusion}

All the previously described Dictyoneura spp. are Pennsylvanian ('Namurian B' or 'Westphalian C or D'), while Dictyoneura goujonorum n. sp. is latest Gzhelian to Asselian, thus the most recent known representative of the genus. The Namurian Dictyoneura kempeli is supposed to have lived in a moist area with rich vegetation along a coastal area in a Variscan foreland basin (Brauckmann 1988). Dictyoneura libelluloides was found in rocks formed in the Westphalian D swamp forests of the intramontane Saar basin (Uhl and Cleal, 2010), similarily to Dictyoneura goujonorum n. sp. Dictyoneura nigra was also found in the Westphalian C of the same area. Thus all these insects probably lived in similar environments, humid but possibly not very warm, even cool. This possible cool temperature could be linked with the proximity 
of relatively high mountains, as suggested by Becq-Giraudon and Van den Driessche (1993) for the Graissessac basin.

The fossil record of the family Dictyoneuridae ranges between the 'Namurian' and the Artinskian (in Central Siberia and Northern China) (Sharov and Sinitshenkova 1977; Hong, 1985). Thus they possibly disappeared because of the global warming which started during the Early Permian and continued after, during the whole Permian. The mean annual temperatures of the period during which they are currently recorded seem to have been under $18^{\circ} \mathrm{C}$ (Scotese et al. 2021: fig. 6). The floristic changes to a 'seed plant-dominated world', due to a supposed global drying, would have happened earlier, around the Permian-Carboniferous boundary (DiMichele et al. 2001). But it seems that the drying was not uniform during the Early Permian, much more serious in the Western part of Pangea than in North China (Yang et al. 2016). Also, the central Siberia was clearly less arid than the central Pangea during the Early to middle Permian (Fujimoto et al. 2012), possibly allowing the survival of the dictyoneurids in these regions at least till the end of the Early Permian. Nevertheless, it seems that the Dictyoneura spp. that were living in the humid (and possibly relatively cool) forests did not survive the earliest Permian. Another explanation for the apparent extinction of these insects could be the rise of some of their predators such as the reptiles, whose diversity increased during the Carboniferous-Permian. But, as some other palaeodictyopterans (e.g some Calvertiellidae; Béthoux et al. 2007) of the same range of body size survived till the end of the Middle Permian, this hypothesis is more unlikely.

\section{Acknowledgements}

We thank two anonymous referees for the very useful comments on the first version of the paper. We sincerely thank Claude and Monique Goujon who found the type specimen and gave it to Sylvie (borned Goujon) and Eric Monceret. We also sincerely thank Eric and Sylvie 
Monceret for the donation of the holotype specimen to the Muséum d'Histoire Naturelle et d'Ethnologie of Colmar. This research was supported by several interdisciplinary programs called "RedPerm I" and "Redperm II", the "Actions Transversales du Muséum" (ATM) of the MNHN, The LabEx Research Program, and the "Projet Fédérateur MNHN" attributed to J-S.S. \& R.G, and A.N. We thank the reviewers XXX and YYY for their constructive remarks.

\section{Disclosure statement}

No potential conflict of interest was reported by the authors.

\section{References}

Agnus A. 1902. Description d'un Neuroptère fossile nouveau. Homoioptera gigantea. Bulletin de la Société Entomologique de France 7:259-261.

Becq-Giraudon JF. 1972. Contribution à l'étude géologique du bassin houiller de Graissessac (Hérault). Unpublished Thèse de 3e cycle, Université de Paris-Sud:1-66.

Becq-Giraudon JF. 1973. Etude géologique du bassin houiller de Graissessac (Hérault). Bulletin du Bureau des Recherches Géologiques et Minières, (deuxième série), Section I 3:151163.

Becq-Giraudon JF, Montenat C, Van Den Driessche J. 1996. Hercynian high-altitude phenomena in the French Massif Central: tectonic implications. Palaeogeography, Palaeoclimatology, Palaeoecology 122:227-241. doi.org/10.1016/0031-0182(95)00081-X

Becq-Giraudon JFVan Den Driessche J. 1994. Dépôts périglaciaires dans le Stéphano-Autunien du Massif central: témoin de l'effondrement gravitaire d'un haut plateau hercynien. Comptes Rendus de l'Académie des Sciences, Paris, (Série II) 318:675-682. pascalfrancis.inist.fr/vibad/index.php?action=getRecordDetail\&idt=4032519 
Bergeron J. 1889. Etude géologique du massif ancien situé au Sud du Massif central. Thèse Paris. Annales de la Société Géologique de France 22:1-362.

Béthoux O, Galtier J, Nel A. 2004. Oldest evidence of insect endophytic oviposition. Palaios 19:408-413. jstor.org/stable/3515864

Béthoux O, Nel A, Schneider JW, Gand G. 2007. Lodetiella magnifica nov. gen. and nov. sp. (Insecta: Palaeodictyoptera; Permian), an extreme situation in wing morphology of palaeopterous insects. Geobios 40:181-189. https://doi.org/10.1016/j.geobios.2006.04.001

Bolton H. 1912. Insect-remains from the Midland and South-Eastern coal measures. Quarterly Journal of the Geological Society 68:310-323. doi.org/10.1144/GSL.JGS.1912.068.01-04.25

Brauckmann C. 1988. Hagen-Vorhalle, a new important Namurian Insecta-bearing locality (Upper Carboniferous; FR Germany). Entomologia Generalis 14:73-79. doi.org/10.1127/entom.gen/14/1988/73

Brauckmann C. 1995. Neue Insekten-Funde (Palaeodictyoptera, Breyeriidae) aus dem Oberkarbon von Osnabruck (Deutschland). Osnasbrucker Naturwissenschaften Mitteilungen, 20-21: 157-166.

Brauckmann C, Koch L. 1983. Eine weitere neue Insektenart aus den Vorhalle-Schichten (Ober-Karbon, oberes Namurium B) von Hagen-Vorhalle. Dortmunder Beiträge zur Landeskunde, Naturwissenschaftliche Mitteilungen 17:3-8.

Brauckmann C, Koch L, Kemper M. 1985. Spinnentiere (Arachnida) und Insekten aus den Vorhalle-Schichten (Namurium B; Ober-Karbon) von Hagen-Vorhalle (West-Deutschland). Geologie und Paläontologie in Westfalen, Westfälisches Museum für Naturkunde 3: 1-132.

Bruguier O, Becq-Giraudon JF, Champenois M, Deloule E, Ludden J, Mangin D. 2003. Application of in situ zircon geochronology and accessory phase chemistry to constraining basin development during post-collisional extension: a case study from the French Massif Central. Chemical Geology 201:319-336. doi.org/10.1016/j.chemgeo.2003.08.005 
Carpenter FM. 1976. The Lower Permian insects of Kansas: Part 12. Protorthoptera

350

351

352 (continued), Neuroptera, additional Palaeodictyoptera \& families of uncertain position. Psyche 83:336-376. doi.org/10.1155/1976/932123

Carpenter FM. 1992. Superclass Hexapoda. In: Moore, R.C., and Kaesler, R.L. (eds). Treatise on Invertebrate Paleontology. The Geological Society of America and the University of Kansas, Boulder, Colorado, (R), Arthropoda 4, 3/4: xxii + 655 pp.

Crônier C, Courville P. 2005. New xiphosuran merostomata from the Upper Carboniferous of the Graissessac Basin (Massif Central, France). Comptes Rendus Palevol 4:123-133. doi.org/10.1016/j.crpv.2004.11.002

de Borre PA. 1875. Notes sur des empreintes d'insectes fossiles découvertes dans les schistes houillers des environs de Mons. Annales de la Société Entomologique de Belgique 18:xxxixxlii.

DiMichele WA, Pfefferkorn HW, Gastoldo RA. 2001. Response of Late Carboniferous and Early Permian plant communities to climate change. Annual Review of Earth and Planetary Sciences 29:461-487. doi.org/10.1146/annurev.earth.29.1.461

Doubinger J, Feist M, Galtier J, Broutin J. 1983. Excursion dans le Paléozoïque et le Mésozoïque de l'Hérault. Montpellier: Livret Guide de la Conférence Européenne de Paléobotanique:1-24.

Doubinger, J., Vetter, P., Langiaux, J., Galtier, J., Broutin, J. 1995. La flore fossile du bassin houiller de Saint-Etienne. Mémoires du Muséum National d'Histoire Naturelle 164:1-357.

Fujimoto T, Otoh S, Orihashi Y, Hirata T, Yokoyama TD, Shimojo M, Kouchi Y, Obara H, Ishizaki Y, Tsukada K, Kurihara T, Nuramkhan M, Gonchigdor S. 2012. Permian Peri-glacial deposits from Central Mongolia in Central Asian orogenic belt: a possible indicator of the Capitanian cooling event. Resource Geology 62:408-422. doi.org/10.1111/j.17513928.2012.00204.x 
Goldenberg F. 1854. Die fossilen Insecten der Kohlenformation von Saarbrücken.

375 Palaeontographica 4:17-38.

376

377

Goldenberg F. 1877. Die fossilen Thiere aus der Steinkohlenformation von Saarbrücken. Fauna Saraepontana Fossilis $2: \mathrm{i}-\mathrm{iv}+1-54$.

Grand'Eury FC. 1877. Mémoire sur la flore carbonifère du département de la Loire et du centre de la France. Mémoires de 1'Académie des Sciences et de l'Institut National de France 24:1624.

Guthörl P. 1930. Neue Insektenfunde aus dem Saarcarbon. Neues Jahrbuch für Mineralogie, Geologie und Paläontologie Abhandlungen Abteilung B 64:147-164.

Guthörl P. 1934. Die Arthropoden aus dem Karbon und Perm der Saar-Nahe-Pfalz-Gebietes. Abhandlungen der Preussischen Geologischen Landesanstalt (Neue Folge) 164:1-219.

Handlirsch A. 1904. Les insectes houillers de la Belgique. Mémoires du Musée Royal d'Histoire Naturelle de Belgique 3:1-20.

Handlirsch A. 1906a (-1908). Die fossilen Insekten und die Phylogenie der rezenten Formen. Ein Handbuch für Paläontologen und Zoologen. Engelman, V.W. publ., Leipzig: 1430 pp.

Handlirsch A. 1910. Das erste fossile Insekt aus dem Oberkarbon Westfalens. Verhandlungen der Kaiserlich-Königlichen Zoologisch-Botanischen Gesellschaft in Wien 60:249-251.

Handlirsch A. 1906b. Revision of American Paleozoic insects. Proceedings of the United States National Museum 29:661-820. doi.org/10.5479/si.00963801.29-1441.661

Handlirsch A. 1919. Revision der Paläozoischen Insekten. Denkschriften der Akademie Wissenschaften, Mathematisch-Naturwissenschaftliche Klasse 96:511-592.

Hong Y-C. 1985. New fossil genera and species of Shanxi Formation in Xishan of Taiyuan. Entomotaxonomia 7:83-91. [in Chinese.]

Kliver M. 1883. Über einige neue Blattinarien, zwei Dictyoneura und zwei Arthropleura-Arten aus der Saarbrücker Steinkohlenformation. Palaeontographica 29:249-269. 
399

400

401

402

403

404

405

406

407

408

409

410

411

412

413

414

415

416

417

418

419

420

421

422

Kukalová J. 1969a. Revisional study of the order Palaeodictyoptera in the Upper Carboniferous shales of Commentry, France. Part I. Psyche 76:163-215. doi.org/10.1155/1969/74019

Kukalová J. 1969b. Revisional study of the order Palaeodictyoptera in the Upper Carboniferous shales of Commentry, France. Part 2. Psyche 76:439-486. doi.org/10.1155/1969/20732

Kukalová J. 1970. Revisional study of the order Palaeodictyoptera in the Upper Carboniferous shales of Commentry, France. Part III. Psyche 77:1-44. doi.org/10.1155/1970/71691

Kukalová-Peck J. 1991. Chapter 6: Fossil history and the evolution of hexapod structures. pp. 141-179. In: Naumann ID. (ed.). The insects of Australia, a textbook for students and research workers (2nd ed.), 1, (Melbourne University Press, Melbourne, CSIRO):542 pp.

Laurentiaux D. 1950. Les insectes houillers du Limbourg hollandais. Mededelingen van de Geologische Stichling 4:13-22.

Laurentiaux,D, Laurentiaux-Vieira F. 1951 (1952). Observations sur les Paléodictyoptères Breyeriidae. Bulletin de la Société Géologique de France (6) 1:585-596.

Laurentiaux-Vieira F, Laurentiaux D. 1986. Paléodictyoptère nouveau du Namurien belge. Annales de la Société Géologique du Nord 105:187-193.

Louis J. 1954. Tectonique des bassins houillers de la bordure orientale du Massif central. Thèse Lyon, A. Lémery ed.:173 pp.

Martín-Closas C, Galtier J. 2005. Plant taphonomy and paleoecology of Late Pennsylvanian intramontane wetlands in the Graissessac-Lodève basin (Languedoc, France). Palaios 20:249265. doi.org/10.2110/palo.2003.p03-119

Martynov AV. 1931. On some remarkable Odonata from the Permian of Archangelsk District. Izvestiya Akademii nauk SSSR 1931:141-147.

Meunier F. 1908. Nouveaux Mégasécoptèrides et un nouveau Paléodictyoptère de Commentry. Bulletin du Museum National d'Histoire Naturelle 14:172-175. 

doi.org/10.1080/08912963.2019.1675055

Özdikmen H. 2008. Some nomenclatural changes for Blattodea and Dictyoneurida (=

427 Palaeodictyoptera). Munis Entomology \& Zoology 3:745-748.

428 Pfeifer LS, Soreghan GS, Pochat S, Van Den Driessche J, Thomson SN. 2018. Permian 429 exhumation of the Montagne Noire metamorphic core complex recorded in provenance of upper 430 Paleozoic clastic strata in the Graissessac-Lodève Basin, France. Basin Research 30:1-14. 431 https://doi.org/10.1111/bre.12197

432 Poschmann M, Dunlop JA, Béthoux O, Galtier J. 2016. Carboniferous arachnids from the 433 Graissessac Basin, Central Massif, France. Paläontologische Zeitschrift 90:33-48. 434 /doi.org/10.1007/s12542-016-0295-7

Prokop J, Ren D. 2007. New significant fossil insects from the Upper Carboniferous of Ningxia in northern China (Palaeodictyoptera, Archaeorthoptera). European Journal of Entomology 104:267-275. doi.org/10.14411/eje.2007.041

438 Prokop J, Pecharová M, Jarzembowski EA, Ross AJ. 2018. New palaeodictyopterans from the 439 Late Carboniferous of the UK (Insecta: Palaeodictyopterida). Earth and Environmental Science 440 Transactions of the Royal Society of Edinburgh 107:99-107. doi.org/10.1017/S1755691017000408

442 Prokop J, Tippeltová S, Roques P, Nel A. 2013. A new genus and species of Breyeriidae and 443 wings of immature stages from the Upper Carboniferous, Nord-Pas-de-Calais, France (Insecta: 444 Palaeodictyoptera). Insect Systematics \& Evolution 44:117-128. doi.org/10.1163/1876312X$445 \quad 44032098$

446 Riek EF. 1976. Neosecoptera, a new insect suborder based on specimen discovered in the late 447 Carboniferous of Tasmania. Alcheringa 1:227-234. doi.org/10.1080/03115517608619072 
Rilliart P. 2013. Le Stéphanien du bassin de Graissessac. 28 septembre 2013, sortie dirigée par

449

450

451

452

453

454

455

456

457

458

459

460

461

462

463

464

465

466

467

468

469

470

471

Philippe Rilliart avec la complicité de Danyck Gourdin et Bernard Guibbert:15 pp.

Saint Martin M. 1993. Evolution du bassin stéphanien de Graissessac en relation avec les tectoniques hercyniennes et tardi-hercyniennes de la Montagne Noire (Sud du Massif Central français). PhD Thesis, Université de Montpellier:89 pp.

Scotese CR, Song H-j, Mills BJW., van der Meer DG. 2021. Phanerozoic paleotemperatures: The earth's changing climate during the last 540 million years. Earth-Science Reviews 215 (103503):1-47. doi.org/10.1016/j.earscirev.2021.103503

Scudder SH. 1885. 4. Classe Insecta. Insecten. Handbuch der Palaeontologie, I Abtheilung. Palaeozoologie 2:747-831.

Sharov AG, Sinitshenkova ND. 1977. New Palaeodictyoptera from the USSR. Paleontological Journal 11:44-59.

Sinitshenkova ND. 1979. A new family of the Palaeodictyoptera from the Carboniferous of Siberia. Paleontological Journal 13:192-205.

Sinitshenkova ND. 1992. Two new insect species (Insecta: Dictyoneurida = Palaeodictyoptera, Perlida $=$ Plecoptera $)$ from the Late Permian of South Mongolia, Trudy Sovmestnaya SovetskoMongol'skaya Paleontologicheskaya Ekspeditsiya 4:98-100.

Sinitshenkova ND. 2002. Chapter 2.2.1.2.3. Superorder Dictyoneurida Handlirsch, 1906 (= Palaeodictyopteroidea). pp. 115-124. In: Rasnitsyn AP, Quicke DLJ. (eds). 2002. History of insects. Kluwer Academic Publishers, Dordrecht, Boston, London:xi + 517 pp.

Sroka P, Staniczek AH, Bechly, G. 2015. Revision of the giant pterygote insect Bojophlebia prokopi Kukalová-Peck, 1985 (Hydropalaeoptera: Bojophlebiidae) from the Carboniferous of the Czech Republic, with the first cladistic analysis of fossil palaeopterous insects. Journal of Systematic Palaeontology 13:963-982. doi.org/10.1080/14772019.2014.987958 
472 Uhl D, Cleal CJ. 2010. Late Carboniferous vegetation change in lowland and intramontane 473 basins in Germany. International Journal of Coal Geology 83:318-328. 474 doi.org/10.1016/j.coal.2009.07.007

475 Waterlot G. 1934. Etude de la faune continentale du terrain houiller sarro-lorrain. In: Bassin 476 houiller de la Sarre et de la Lorraine. 2. Faune fossile. Etude des Gites Minéraux de la France, 477 Imprimerie L. Danel, Lille:1-317.

478 Yang J-h, Cawood PA, Du Y-s, Li W-q, Yan J-x. 2016. Reconstructing the Early Permian 479 tropical climates from chemical weathering indices. Geological Society of America Bulletin 480 128:739-751. doi.org/10.1130/B31371.1

481

482 Figure 1. Geological map of Carboniferous Graissessac basin (modified from Martín-Closas 483 and Galtier 2005: fig. 1; Becq-Giraudon 1973; Saint Martin 1973; Pfeifer et al. 2018).

484

485

Figure 2. Dictyoneura goujonorum n. sp., holotype: MHNE.2021.3.1. Imprint. (A) forewing; 486 (B) hind wing; (C) forewing under alcohol; (D) hind wing under alcohol; (E) drawing of 487 forewing. Scale bars $10 \mathrm{~mm}$. 
$A$ $+$ Sist

C
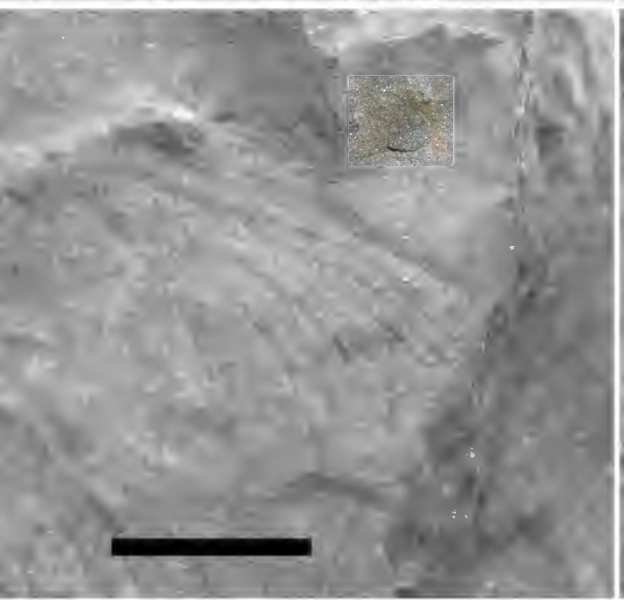

D

E

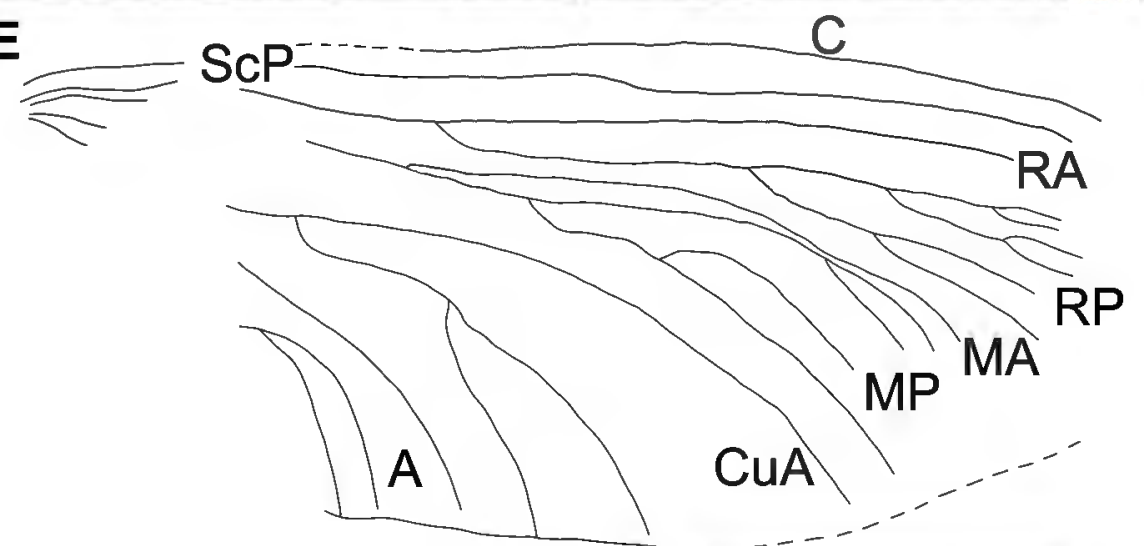

CuP

Cu $M$ RP 